\title{
ECONOMIC PERFORMANCE BESERTA FAKTOR-FAKTORNYA
}

\author{
Indra Gunawan Siregar ${ }^{1 *}$, Dirvi Surya Abbas ${ }^{2}$ Basuki $^{3}$ \\ 1,2,3 Universitas Muhammadiyah Tangerang \\ gunawan.sloww@yahoo.co.id, abbas.dirvi@gmail.com
}

\begin{abstract}
ABSTRAK
Tujuan dari penelitian ini untuk mengetahui pengaruh price earning ratio, net profir margin dan environmental disclosure terhadap economic performance pada perusahaan property dan real estate yang terdaftar di Bursa Efek Indonesia (BEI). Periode waktu penelitian yang digunakan adalah 4 tahun yaitu periode 2015-2018. Populasi penelitian ini meliputi seluruh perusahaan property dan real estate estate yang terdaftar di Bursa Efek Indonesia (BEI) periode 2015-2018. Teknik pengambilan sampel menggunakan teknik purposive sampling. Berdasarkan kriteria yang telah ditetapkan diperoleh 8 perusahaan. Jenis data yang digunakan adalah data sekunder yang diperoleh dari situs Bursa Efek Indonesia. Metode analisis yang digunakan adalah analisis regresi data panel. Hasil penelitian menunjukkan bahwa net profir margin berpengaruh signifikan terhadap economic performance, price earning ratio dan environmental disclosure tidak berpengaruh signifikan terhadap economic performance. Price earning ratio, net profir margin dan environmental disclosure secara bersama- sama berpengaruh terhadap economic performance.
\end{abstract}

Kata Kunci : economic performance, price earning ratio, net profit margin dan environmental disclosure

\section{PENDAHULUAN}

Kinerja ekonomi atau economic performance diungkapkan dalam laporan keuangan tahunan perusahaan. Dengan melihat kinerja ekonomi yang baik dapat memberikan gambaran yang baik dan jelas tentang keberhasilan suatu perusahaan. Dalam upaya untuk mengetahui kinerja ekonomi perusahaan dengan tepat, banyak sekali teknik pengukuran kinerja yang telah dibuat dan dipakai oleh kalangan pemilik modal maupun para manajer perusahaan. Salah satu cara untuk mengetahui kinerja perusahaan adalah dengan melakukan analisis terhadap kondisi keuangan perusahaan yang tercermin dalam rasio- rasio keuangan perusahaan.

Kinerja ekonomi atau economic performance adalah suatu usaha formal yang dilaksanakan perusahaan untuk mengevaluasi efisien dan efektivitas dari aktivitas keuangan perusahaan yang telah dilaksanakan pada periode waktu. Economic Performance dapat diukur dari laporan keuangan perusahaan yang dikeluarkan secara periodik yang memberikan suatu gambaran tentang posisi keuangan perusahaan. Informasi yang terkandung dalam laporan keuangan digunakan oleh investor untuk memperoleh perkiraan tentang laba dan dividen di masa mendatang dan resiko atas penilaian tersebut.

Tuntutan economic performance etis berimplikasi pada perwujudan aktivitas industri sebagai interaksi harmonis antara stakeholders (pihak-pihak yang berkepentingan) dengan shareholders atau para pelaku bisnis itu sendiri. Oleh karena itu, semua tindakan bisnis dan economic performance akan menjadi penilaian para stakeholders. Semakin etis para pelaku bisnis, maka tujuan perusahaan akan tercapai dengan sendirinya dan bisnisnya akan berjalan dalam koridor yang diharapkan. Saat ini para stakeholder semakin peduli dengan isu-isu lingkungan yang ada. Menurut laporan Ernst \& Young 40\% dari proposal yang diajukan pemegang saham bertemakan lingkungan dan sosial. Hal ini menunjukan bahwa para pemegang saham menuntut perusahaan agar lebih memerhatikan isu-isu lingkungan dan sustainable development. 
Isu mengenai economic performance ditandai dengan pertumbuhan ekonomi Indonesia berkembang cukup baik terutama setelah adanya krisis ekonomi di tahun 1998. Lembaga Penyelidikan Ekonomi dan Masyarakat (LPEM) Fakultas Ekonomi Universitas Indonesia (FE UI) 2018 memproyeksikan pertumbuhan pertumbuhan ekonomi di Indonesia mengalami sedikit peningkatan dari 5,2\% ditahun 2018 menjadi $5,3 \%$ ditahun 2019. (www.kontan.co.id, diakses Mei 2019). Seiring dengan meningkatnya ativitas perdagangan, masyarakat dan investor membutuhkan adanya sarana informasi yang relevan mengenai kondisi perkembangan bursa saham. Semua emiten yang tercatat dalam Bursa Efek Indonesia (BEI) diklasifikasikan kedalam sembilan sektor menurut klasifikasi industri yang telah ditetapkan BEI.

Dampak ekonomi kapitalis telah menjalar pada dunia industri saat ini. Kapitalis merupakan suatu paham yang meyakini bahwa pemilik modal bisa melakukan usahanya untuk meraih keuntungan sebesar-besarnya. Banyak perusahaan yang telah menerapkan hal tersebut dengan memaksimalkan laba namun disamping itu mereka telah melanggar konsensus dan prinsip maksimal laba itu sendiri. Prinsipprinsip yang dilanggar antara lain yakni, kaidah biaya ekonomi (economic cost), biaya akuntansi (accounting cost), dan biaya kesempatan (opportunity cost). Implikasi dari pelanggaran-pelanggaran tersebut adalah terbengkalainya pengelolaan lingkungan dan rendahnya tingkat kinerja lingkungan serta rendahnya perusahaan terhadap pengungkapan lingkungan.

Variabel pertama yakni Price Earning Ratio (PER) yang digunakan untuk menghitung tingkat pengembalian modal yang diinvestasikan pada suatu saham. Price earning ratio merupakan rasio keuangan yang mengukur harga pasar relative terhadap nilai buku (Hanafi, 2016: 82 dalam (Kalbuana, 2017). Semakin tinggi rasio PER akan mengindikasi bahwa kinerja perusahaan semakin membaik. Hal tersebut dikarenakan semakin tinggi PER saham suatu perusahaan, maka harga perlembar saham akan cenderung meningkat, jadi apabila harga perlembar saham dan tingkat pertumbuhan laba suatu perusahaan meningkat maka PER dan return saham juga meningkat. Akan tetapi jika PER terlalu tinggi juga daat mengindikasikan bahwa harga saham yang ditawarkan sudah sangat tinggi atau tidak rasional. Apabila harga perlembar saham dan pertumbuhan laba suatu perusahaan menurun maka PER juga menurun dan return saham juga mengalami penurunan. Oleh sebab itu, diperlukan kehati- hatian dalam menganalisis PER untuk pasar modal. Dalam penelitian Haruman (2005) dan Mila Christanty (2009) menunjukkan bahwa PER berpengaruh positif dan signifikan terhadap tingkat pengembalian saham.

Net Profit Margin (NPM) yang merupakan rasio antara laba bersih setelah pajak atau net income after tax dengan penjualan bersih atau net sales. Net Profit Margin (NPM) merupakan rasio yang menunjukkan seberapa besar persentase laba bersih yang diperoleh dari setiap penjualan (Rinati, 2001: 75 dalam (Nominal, 2012)). Rasio ini menginterpretasikan tingkat efisiensi perusahaan, yakni sejauh mana kemampuan perusahaan menekan biaya-biaya operasionalnya pada periode tertentu. Semakin besar nilai NPM menunjukkan tingginya kemampuan perusahaan dalam menghasilkan laba bersih. Dengan kemampuan perusahaan dalam menghasilkan laba bersih yang semakin tinggi, diharapkan mampu memberikan pengaruh positif terhadap kinerja ekonomi (economic performance). Sebaliknya, jika rasio ini semakin turun maka kemampuan perusahaan dalam mendapatkan laba melalui penjualan dianggap cukup rendah. Selain itu, kemampuan perusahaan dalam menekan biayabiayanya dianggap kurang baik sehingga investor pun enggan untuk menanamkan dananya. Dalam penelitian Susilowati (2011) 
dimana hasil penelitian menunjukkan bahwa NPM berpengaruh signifikan terhadap economic performance.

Environmental Disclosure yang merupakan pengungkapan informasi yang berkaitan dengan lingkungan di dalam laporan perusahaan. Terdapat 13 item environmental disclosure yang wajib diungkapkan dalam catatan atas laporan keuangan perusahaan pemegang HPH/HPHTI. Praktik pengungkapan lingkungan memegang peranan penting bagi hidup perusahaan yang tentunya perusahaan beroperasi ditengah lingkup masyarakat dan mungkin terjadi dampak akibat adanya aktivitas perusahaan. Praktik ini umumnya digunakan oleh manajer dalam menghindari konflik sosial dan lingkungan (Ghozali dan Chariri, 2007: 403 dalam (Ihsan, 2017)). Dalam penelitian environmental disclosure yang diteliti Naratama (2015), menunjukkan hasil penelitian berpengaruh signifikan terhadap economic performance.

\section{KAJIAN PUSTAKA PENGEMBANGAN HIPOTESIS} Teori Akuntansi Positif

Positive accounting theory atau teori akuntansi positif pertama kali dikenalkan oleh Watt \& Zimmerman (1986). Teori ini berusaha menjelaskan dan menjawab alasan mengapa praktik akuntansi dilakukan serta memberikan prediksi atas peran akuntansi dan informasi dalam pengambilan keputusan ekonomi dari individu, perusahaan ataupun pihak terkait lainnya. Dengan menggunakan teori akuntansi positif ini, dapat diketahui motivasi suatu perusahaan melakukan revaluasi aset.

Watt \& Zimmerman (1986) juga mengemukakan tiga hipotesis yang berkaitan dengan perilaku oportunistik manajemen. Pertama, bonus plan hypothesis, menyatakan seorang manajer akan memilih suatu model akuntansi guna meningkatkan kompensasi yang akan didapatkannya. Kedua, debt covenant hypothesis, pemilihan suatu model akuntansi dilakukan guna mengurangi kemungkinan pelanggaran persyaratan utang maupun perjanjian obligasi. Ketiga, political hypothesis cost, menunjukkan bahwa perusahaan dengan ukuran besar akan lebih memilih model akuntansi yang dapat menurunkan laba perusahaan dalam laporan keuangan.

\section{Stewardship Theory}

Stewardship theory (Donaldson dan Davis: 1991 dalam (Ravi, Pramod Kumar, \& Siddaramaiah, 2012)), menggambarkan bahwa tidak ada suatu keadaan situasi para manajemen termotivasi untuk tujuan-tujuan individu melainkan lebih fokus untuk tujuan sasaran utama yaitu kepentingan organisasi. Asumsi filosofi mengenai teori stewardship dibangun berdasarkan sifat manusia yaitu dapat dipercaya, mampu bertindak dengan penuh tanggung jawab, memiliki integritas, serta dapat berlaku jujur untuk pihak lainnya. Dengan kata lain, stewardship theory memandang bahwa manajemen dapat berperilaku baik untuk kepentingan publik dan umumnya maupun shareholders pada khususnya. Teori ini menggambarkan hubungan yang kuat antara kepuasan dan kesuksesan organisasi. Tercapainya kesuksesan dalam sebuah organisasi dapat dicapai dengan cara maksimalisasi utilitas principals dan manajemen. Teori stewardship dapat diterapkan dalam penelitian akuntansi organisasi sektor publik seperti organisasi pemerintahan dan non profit lainnya.

\section{Economic Performance}

Economic performance adalah kinerja perusahaan secara relatif (berubah-berubah dari tahun ke tahun) dalam suatu industri sejenis (industri yang bergerak dalam usaha yang sama) yang ditandai dengan return tahunan perusahaan tersebut (Almilia \& Wijayanto, 2007). Untuk memantapkan kinerja ekonomi atau economic performance perusahaan menempuh berbagai cara termasuk memacu laju investasi. Dengan nilai investasi 
yang meningkat maka beberapa indikator ekonomi bisa terpacu. Di dalam penelitian ini, ukuran kinerja yang digunakan adalah kinerja saham perusahaan yang diukur dengan return saham (capital market-based measure).

Pengukuran kinerja ekonomi menurut Kamus Istilah Akuntansi (2003) menyatakan bahwa economic performance adalah suatu istilah yang digunakan untuk sebagian atau seluruh tindakan aktivitas dari suatu organisasi pada suatu periode, sering dengan referensi pada sejumlah standar seperti biaya masa lalu atau yang diproyeksikan, suatu dasar efisiensi, pertanggungjawaban atau akuntabilitas manajemen dan semacamnya. Kinerja keuangan merupakan salah satu faktor yang menunjukkan efektivitas dan efesien suatu perusahaan dalam rangka mencapai tujuannya.

\section{Pengaruh Price Earning Ratio terhadap Economic Performance}

Semakin tinggi nilai EPS tentu saja menggembirakan para pemegang saham karena semakin besar laba yang disediakan untuk pemegang saham. Semakin besar nilai EPS tentunya semakin banyak investor yang ingin menanamkan modalnya. Perusahaan dengan peluang tingkat pertumbuhan yang tinggi, biasanya memiliki PER yang tinggi. Apabila nilai PER suatu perusahaan lebih tinggi, maka menunjukkan bahwa pasar bersedia membayar lebih terhadap pendapatan atau laba suatu perusahaan, serta memiliki harapan yang tinggi terhadap masa depan perusahaan tersebut. Hal tersebut dikarenakan semakin tinggi PER saham suatu perusahaan, maka harga perlembar saham akan cenderung meningkat, jadi apabila harga perlembar saham dan tingkat pertumbuhan laba suatu perusahaan meningkat maka return saham juga meningkat. Menurut Ayu dan Gede (2018) PER berpengaruh positif dan signifikan terhadap return saham (economic performance). Begitupun penelitian yang dilakukan oleh Yeye Susilowati (2011) PER berpengaruh negatif dan tidak signifikan terhadap return saham.
H1: Price earning ratio berpengaruh signifikan terhadap economic performance

\section{Pengaruh Net Profit Margin terhadap Economic Performance}

NPM menunjukkan berapa besar persentase laba bersih yang diperoleh dari setiap penjualan (Rinati, 2001: 75 dalam (Nominal, 2012)). NPM yang tinggi dapat menunjukkan kinerja perusahaan yang bagus karena dapat menghasilkan laba bersih yang besar melalui aktivitas penjualannya sehingga saham perusahaan tersebut banyak diminati investor. Rasio ini mengukur kemampuan perusahaan menghasilkan pendapatan bersihnya terhadap total penjualan yang dicapai oleh perusahaan tersebut. Jadi kinerja keuangan perusahaan dalam menghasilkan laba bersih atas penjualan semakin meningkat maka hal ini akan berdampak pada meningkatnya pendapatan yang diterima oleh pemegang saham. NPM yang semakin meningkat menggambarkan kinerja perusahaan yang semakin baik dan keuntungan yang diperoleh pemegang saham akan meningkat pula (Robert Ang, 1997 dalam (Gede dan Artini, 2018)). Dalam penelitian Net Profit Margin yang diteliti Ayu dan Gede (2018) hasil penelitian menunjukkan bahwa NPM berpengaruh signifikan terhadap economic performance. Sedangkan Machfoedz (1994) menunjukkan hasil bahwa NPM tidak berpengaruh signifikan terhadap laba perusahaan.

$\mathrm{H} 2$ : Net profit margin berpengaruh signifikan terhadap economic performance

\section{Pengaruh Environmental Disclosure terhadap Economic Performance}

Aktivitas yang dilakukan oleh perusahaan akan memiliki berbagai dampak terhadap lingkungan internal maupun eksternal perusahaan. Saat ini perusahaan dituntut untuk mengelola dampak kegiatan perusahaan agar memungkinkan terciptanya pembangunan berkelanjutan. Pembangunan berkelanjutan tersebut tentunya hanya akan dapat diraih 
apabila sejak sekarang perusahaan-perusahaan melakukan pengelolaan dampak operasi perusahaan. Perusahaan yang memiliki pengungkapan baik lebih cenderung akan meningkatkan environmental disclosure dalam laporan tahunannya. Sehingga dalam hal ini environmental disclosure akan direspon secara positif bagi economic performance. Perusahaan melakukan pengungkapan informasi sosial dengan tujuan untuk membangun image pada perusahaan dan mendapatkan perhatian dari masyarakat. Perusahaan yang dinilai sebagai perusahaan beresiko lingkungan tinggi adalah perusahaan yang menggunakan model proses produksinya memanfaatkan secara langsung sumber daya alam. Dalam penelitian Reza dan Naratama (2015), menunjukkan hasil berpengaruh signifikan terhadap economic performance.

H3: Environmental disclosure berpengaruh signifikan terhadap economic performance

\section{METODOLOGI PENELITIAN}

\section{Populasi dan Sampel}

Dalam penelitian ini metode pengumpulan data yang dilakukan menggunakan pendekatan kuantitatif yang menghasilkan data deskriptif berupa angkaangka yang digunakan dalam penelitian, berkaitan dengan tata cara pengumpulan data yang diperoleh dari jurnal, penelitian terdahulu literatur dan daftar pustaka.Penelitian ini dilakukan berdasarkan laporan keuangan tahunan ada perusahaan sub sektor property dan real estate periode 2014-2018 yang terdaftar di Bursa Efek Indonesia.

\section{Analisis Regresi Data Panel}

Menurut Sriyana (2014:77) data panel adalah penggabungan antara data time series (runtun waktu) dengan cross section (data silang). Penggunaan data panel dapat menjelaskan dua macam informasi yaitu informasi antar unit (cross section) pada perbedaan antar subjek, dan informasi antar waktu (time series) yang mereflesikan perubahan pada subjek waktu. Dalam Penelitian ini model regresi data panel dapat ditulis sebagai berikut (Sriyana, 2014:82) :

$$
\mathrm{EP}=\alpha+\beta 1 \mathrm{PER}+\beta 2 \mathrm{NPM}+\beta 3 \mathrm{ED}+\mathrm{e}
$$

\section{HASIL PENELITIAN DAN PEMBAHASAN}

Tabel 1 Analisis Statistik Deskriptif

\begin{tabular}{|l|c|c|c|c|}
\hline & EP & PER & NPM & ED \\
\hline Mean & 0.007688 & 18.63494 & 0.288281 & 0.529500 \\
\hline Median & 0.000000 & 15.42000 & 0.280000 & 0.471000 \\
\hline Maximum & 0.377000 & 50.77100 & 0.599000 & 0.794000 \\
\hline Minimum & -0.312000 & 3.351000 & 0.077000 & 0.235000 \\
\hline Std. Dev. & 0.148589 & 11.04995 & 0.152985 & 0.155557 \\
\hline Skewness & 0.347140 & 1.619277 & 0.255799 & 0.146055 \\
\hline Kurtosis & 3.395796 & 5.234415 & 1.722377 & 1.959085 \\
\hline Jarque-Bera & 0.851573 & 20.64112 & 2.525406 & 1.558442 \\
\hline Probability & 0.653256 & 0.000033 & 0.282888 & 0.458763 \\
\hline Sum & 0.246000 & 596.3180 & 9.225000 & 16.94400 \\
\hline $\begin{array}{l}\text { Sum Sq. } \\
\text { Dev. }\end{array}$ & 0.684435 & 3785.142 & 0.725536 & 0.750138 \\
\hline Observations & 32 & 32 & 32 & 32 \\
\hline
\end{tabular}

Hasil dari analisis statistik deskriptif terhadap variabel economic performance menunjukkan nilai rata-rata sebesar 0.007688 , dimana rata- rata economic performance yang diperoleh oleh perusahaan sub sektor property dan real estate menggambarkan nilai yang kurang baik yang artinya sebagian besar perusahaan memiliki return yang cukup rendah. Hal ini bisa dilihat dari segi perusahaan property dan real estate yang tidak terus menerus membagikan deviden setiap tahun karena perusahaan yang membagikan deviden setiap tahunnya lebih memiliki daya tarik yang menarik bagi investor untuk berinvestasi di perusahaan tersebut. Dari perusahaan sampel yang diteliti tidak semua perusahaan property dan real estate, terdapat perusahaan yang membagikan deividen secara terus menerus.

Hasil dari analisis statistik deskriptif terhadap variabel price earning ratio menunjukkan nilai rata-rata sebesar 18.63494 , 
dimana rata- rata price earning ratio yang diperoleh oleh perusahaan sub sektor property dan real estate menggambarkan nilai yang cukup besar yang artinya laba yang didapat perlembar sahamnya cukup besar. Hal ini menggambarkan adanya dampak terhadap economic performance karena apabila nilai PER suatu perusahaan lebih tinggi, maka menunjukkan bahwa pasar bersedia membayar lebih terhadap pendapatan atau laba suatu perusahaan, serta memiliki harapan yang tinggi terhadap masa depan perusahaan tersebut.

Hasil dari analisis statistik deskriptif terhadap variabel net profit margin menunjukkan nilai rata-rata sebesar 0.288281, dimana rata-rata net profit margin yang diperoleh oleh perusahaan sub sektor property dan real estate menggambarkan nilai yang cukup besar yang artinya keuntungan bersih dalam setiap penjualan bisa mencapai $28 \%$ per tahun. Hal ini menggambarkan adanya dampak yang baik bagi economic performance, dengan presentase laba bersih yang besar diharapkan para investor tertarik untuk berinvestasi di perusahaan property dan real estate. NPM yang tinggi dapat menunjukkan kinerja perusahaan yang bagus karena dapat menghasilkan laba bersih yang besar melalui aktivitas penjualannya sehingga saham perusahaan tersebut banyak diminati investor. Jadi kinerja keuangan perusahaan dalam menghasilkan laba bersih atas penjualan semakin meningkat maka hal ini akan berdampak pada meningkatnya pendapatan yang diterima oleh pemegang saham.

Hasil dari analisis statistik deskriptif terhadap variabel environmental disclosure menunjukkan nilai rata-rata sebesar 0.529500, dimana rata-rata environmental disclosure yang diperoleh oleh perusahaan sub sektor property dan real estate menggambarkan nilai yang baik, artinya terdapat setengah dari perusahaan property dan real estate yang mulai peduli dan menyampaikan environmental disclosure pada laporan tahunan perusahaan meskipun dari segi kewajiban pengungkapan perusahaan property dan real estate merupakan perusahaan yang melalukan pengungkapan sifatnya sukarela.

Pengujian terhadap hipotesis penelitian menggunakan analisis regresi data panel. Uji regresi data panel berfungsi untuk menjelaskan hubungan antara variabel bebas dan terikat yang di interprestasikan melalui suatu persamaan yang telah dibuat. Hasil perhitungan analisis regresi data panel dilakukan dengan program eviews 9,2020. Seperti yang ditampilakan pada tabel 2

Tabel 2 Rangkuman Hasil Analisis Regresi Data Panel

\begin{tabular}{|l|l|l|l|}
\hline \multicolumn{1}{|c|}{ Hipotesis } & $\begin{array}{l}\text { Nilai (t- } \\
\text { statistik) }\end{array}$ & Sign. & Ket \\
\hline Constant & -1.936048 & 0.0630 & - \\
\hline $\begin{array}{l}\text { Price Earning Ratio } \\
(\mathrm{H} 1)\end{array}$ & 1.593748 & 0.1222 & Ditolak \\
\hline Net Profit Margin (H2) & 3.830893 & 0.0007 & Diterima \\
\hline $\begin{array}{l}\text { Environmental } \\
\text { Disclosure (H3) }\end{array}$ & -0.752747 & 0.4579 & Ditolak \\
\hline Adjusted $\mathrm{R}-$ squared & 0.275422 & & \\
\hline Prob F Statistik & 4.927837 & \\
\hline
\end{tabular}

\section{Pengaruh Price Earning Ratio terhadap Economic Performance}

Hasil pengujian statistik dengan koefisien regresi sebesar 0.003942 dan nilai tstatistic PER (1.593748) < nilai tabel $(2,04841)$ dengan tingkat signifikan $0.1222>\alpha 0,05$ atau lebih besar dari taraf signifikan 0,05. Berdasarkan hasil tersebut maka dapat dikatakan bahwa price earning ratio tidak berpengaruh terhadap economic performance.

Hasil penelitian ini tidak sejalan dengan hasil penelitiaan sebelumnya yang telah dilakukan oleh Tendi Haruman (2005) dan Mila Christanty (2009) yang menyatakan bahwa PER berpengaruh positif dan signifikan terhadap tingkat pengembalian saham. Namun hasil penelitian ini sejalan dengan hasil penelitian sebelumnya yang dilakukan oleh Octasari (2006) yang diulas oleh Septiana Rizky Kusumastuti (2009) yang menyatakan hasil 
bahwa PER tidak berpengaruh signifikan terhadap return saham.

Berdasarkan hasil penelitian bahwa price earning ratio tidak berpengaruh pada economic performance dikarenakan price earning ratio yang tinggi tidak menjamin bahwa akan banyak investor yang akan membeli saham perusahaan tersebut. Hal ini dikarenakan masih banyak faktor yang mempengaruhi harga saham seperti stock split dan index harga saham. Selain itu seorang calon investor tidak hanya melakukan analisis fundamental melainkan juga dengan analisis teknikal yang memperhatikan kondisi pasar karena saham sangat rentang terhadap permintaan dan penawaran pasar.

\section{Pengaruh Net Profit Margin terhadap Economic Performance}

Hasil pengujian statistik dengan koefisien regresi sebesar 0.651687 dan nilai t-statistik NPM (3.830893) > nilai t-tabel $(2,04841)$ dengan tingkat signifikan $0.0007<\alpha 0,05$ atau lebih kecil dari taraf signifikan 0,05. Hasil penelitian ini sejalan dengan hasil penelitian sebelumnya yang dilakukan oleh Kadek Ayu dan Luh Gede (2018) yang menyatakan bahwa net profit margin berpengaruh positif dan signifikan terhadap return saham. Sedangkan penelitian ini tidak sejalan dengan hasil penelitian yang dilakukan oleh Nawang dan Suroso (2017) yang menyatakan bahwa net profit margin tidak berpengaruh terhadap return saham.

Berdasarkan hasil penelitian bahwa net profit margin berpengaruh pada economic performance dikarenakan net profit margin merupakan rasio profitabilitas yang menunjukkan presentase laba bersih yang diperoleh dari setiap penjualan. Hal ini dapat dilihat apabila presentase tersebut memiliki nilai yang tinggi dapat membuktikan bahwa economic performance perusahaan propety dan real estate mengalami kinerja yang baik. Begitupun sebaliknya, apabila net profit margin perusahaan tersebut memiliki nilai presentase yang rendah akan menggambarkan economic performance yang kurang baik.

\section{Pengaruh Environmental Disclosure terhadap Economic Performance}

Hasil pengujian statistik koefisien regresi sebesar -0.117802 dan nilai t-statistik ED ( $0.752747)<$ nilai t-tabel $(2,04841)$ dengan tingkat signifikan $0.4579>\alpha 0,05$ atau lebih besar dari taraf signifikan 0,05 . Hasil penelitian ini tidak sejalan dengan hasil penelitiaan sebelumnya yang telah dilakukan oleh Luciana dan Dwi Wijayanto (2007) yang menyatakan bahwa environmental disclosure berpengaruh positif terhadap economic performance. Namun hasil penelitian ini sejalan dengan hasil penelitian sebelumnya yang dilakukan oleh Adi Gunawan Wibisono (2011) dan Eiffeliena Nurini (2010) yang menyatakan bahwa environmental disclosure tidak berpengaruh terhadap economic performance.

Berdasarkan hasil penelitian bahwa environmental disclosure tidak berpengaruh pada economic performance. Hasil ini menunjukkan economic performance suatu perusahaan tidak dilihat melalui pengungkapan yang dilakukan perusahaan tetapi kebanyakan hanya dilihat melalui keuntungan yang diperoleh perusahaan. Para pelaku pasar di Indonesia cenderung hanya melihat dan merespon informasi yang terjadi di pasar sebatas informasi yang diberikan dan tidak melihat apa saja yang diungkapkan perusahaan prihal lingkungannya sehingga tidak mempengaruhi kinerja ekonomi suatu perusahaan mayoritas pelaku hanya melihat return yang dihasilkan perusahaan setiap tahunnya.

\section{KESIMPULAN}

Price earning ratio tidak berpengaruh terhadap economic performance. Hal ini dikarenakan masih banyak faktor yang mempengaruhi harga saham seperti stock split dan index harga saham. Selain itu seorang calon investor tidak hanya melakukan analisis fundamental melainkan juga dengan analisis 
teknikal yang memperhatikan kondisi pasar karena saham sangat rentang terhadap permintaan dan penawaran pasar. Net profit margin berpengaruh terhadap economic performance. Hal ini dapat dilihat apabila presentase tersebut memiliki nilai yang tinggi dapat membuktikan bahwa economic performance perusahaan propety dan real estate mengalami kinerja yang baik. Begitupun sebaliknya, apabila net profit margin perusahaan tersebut memiliki nilai presentase yang rendah akan menggambarkan economic performance yang kurang baik. Dan Environmental Disclosure tidak berpengaruh terhadap economic performance. Para pelaku pasar di Indonesia cenderung hanya melihat dan merespon informasi yang terjadi di pasar sebatas informasi yang diberikan dan tidak melihat apa saja yang diungkapkan perusahaan prihal lingkungannya sehingga tidak mempengaruhi kinerja ekonomi suatu perusahaan mayoritas pelaku hanya melihat return yang dihasilkan perusahaan setiap tahunnya. Diharapkan penelitian selanjutnya memperluas sampel dan perioe penelitian yang tidak hanya dari perusahaan sub sektor property dan real estate saja, dikarenakan sifat pengungkapan yang masih sukarela.

\section{DAFTAR PUSTAKA}

Almilia, L. S., \& Wijayanto, D. 2007. Pengaruh Environmental Performance Terhadap Environmental Disclosure dan Economic Performance. Proceedings The 1st Accounting Conference.

Artini, L. G. S., \& Yuliaratih, K. A. S. 2018. Variabel yang Mempengaruhi Return Saham pada Perusahaan Property dan Real Estate di Bursa Efek Indonesia. E-Jurnal Ekonomi dan Bisnis Universitas Udayana.

Basuki, A. T. 2016. Analisis Regresi dalam Penelitian Ekonomi dan Bisnis. Yogyakarta: Rajawali Pers.

Dirvi Surya Abbas, Arry Eksandy. (2020). The Effect Of Effective Tax Rate, Tunneling Incentive, And Exchange Rate On Company Decisions To Transfer Pricing : Food And Consumption Sub-Sector Companies Listed
On The Indonesia Evidence. Palarch's Journal Of Archaeology Of Egypt / Egyptology, 17(7), 14430-14442. Retrieved From

Https://Archives.Palarch.Nl/Index.Php/Jae/Ar ticle/View/5486

Eksandy, Arry. 2018. Metode Penelitian Akuntansi dan Manajemen. Tangerang. Ghozali, I. \& Chariri. 2007. Teori Akuntansi. Semarang: Badan Penerbit Universitas Diponegoro.

Ihsan, M. 2017. Pengaruh Environmental Performance dan Environmental Disclosure Terhadap Economic Performance (Studi Empiris pada Perusahaan Manufaktur yang Terdaftar di Bursa Efek Indonesia Tahun 2014-2016). Skripsi. Fakultas Ekonomi dan Bisnis. Universitas Islam Negri Syarif Hidayatullah.

Ikhsan, A. 2008. Akuntansi Lingkungan dan Pengungkapannya. Yogyakarta: Graha Ilmu. Jogiyanto, 2003.Teori Portofolio dan Analisis Investasi. Edisi Ke-3. Yogyakarta: BPFE.

Kalbuana, N. 2017. Pengaruh Leverage, Net Profit Margin dan Price Earning Ratio Terhadap Return Saham Pada Perusahaan Lq 45 Bursa Efek Indonesia. Akuntansi. Seminar Nasional dan The 4th Call for Syariah Paper. Kasmir. 2016. Analisis Laporan Keuangan. Jakarta: Raja Grafindo Persada.

Naratama, R. P., \& Majidah. 2011. Pengaruh Environmental Performance dan Environmental Disclosure Terhadap Return Saham pada Perusahaan Non Keuangan yang Mengikuti PROPER dan Terdaftar di Bursa Efek Indonesia 2010-2011). (1), 1-8.

Raharjo, Eko. 2012. Teori Agensi dan Teori Stewarship dalam Perspektif Akuntansi. Fokus Ekonomi, Volume 2. No 1.

Sugiyono. 2016. Metode Penelitian Kuantitatif, Kualitatif, dan R\&D. Bandung: Alfabet.

Sekaran, Uma. 2014. Metodologi Penelitian untuk Bisnis. Buku 1 Edisi 4. Jakarta: Salemba Empat.

Suratno, D. \& Mutmainah, S. 2006. Pengaruh Environmental Performance Terhadap Environmental Disclosure dan Economic Performance. Simposium Nasional Akuntansi IX Padang. 